\title{
Rebuilding Babel: finding common development solutions using cross-contextual comparisons of multidimensional well-being ${ }^{*}$
}

\author{
James R. Hull ${ }^{* *}$ \\ Gilvan Guedes ${ }^{* *}$
}

In this paper the theoretical tradition of coping strategies and capital portfolios is used as the basis for adaption and combination of existing methodologies to analyze well-being in rural households. Special attention is given to comparisons among different contexts. First we estimate a multidimensional measurement of poverty based on fuzzy logic for two areas of rural frontiers: Nang Rong, Thailand, and Altamira, in the Amazon Basin in Brazil. To enable a cross-contextual comparison we calculated a second estimate using a subset of shared measurements in the two areas. The findings suggest that the pattern of responses on a range of numerous key variables - including education, income and demographic dependency ratio - is robust for the model specification. It is concluded that comparative generalizations, useful in formulating cost-effective public policy interventions across contexts, could be satisfactorily identified in many situations. More generically, this approach provides researchers and policymakers with a framework for understanding the interaction of contexts with the subjective construction of well-being. The understanding of this interaction is useful for distinguishing stable corollaries of poverty from those that are volatile across contexts.

Keywords: Multidimensional poverty. Amazonia. Thailand. Cross-site comparison. Grade of membership.

\footnotetext{
* This research is based on data from two large research projects. The Nang Rong Survey Project is a collaborative effort between investigators at the University of North Carolina, Carolina Population Center and investigators at the Institute for Population and Social Research (IPSR), Mahidol University, Salaya, Thailand. It is partially funded by grant R01-HD25482 from the Eunice Kennedy Shriver National Institute of Child Health and Human Development to the Carolina Population Center, University of North Carolina at Chapel Hill. Data from Altamira comes from the NIH-funded project "Amazonian Deforestation and the Structure of Households", grant R01-HD35811-09. The project is a collaborative effort between investigators at Indiana University, Anthropological Center for Training and Research on Global Environmental Change and investigators at the Population Study Center, Campinas State University, Brazil. Persons interested in obtaining data files from the Nang Rong Survey Project should contact The Nang Rong Survey Project, Carolina Population Center, 123 W. Franklin Street, CB\# 8120, Chapel Hill, NC 27516-3997 (email: nangrong@unc.edu).

** Lecturer, PSOE -School of Social Sciences, University of California, Irvine (james.hull@uci.edu)

${ }^{* * *}$ Associate Professor, Department of Demography - Core Faculty, Cedeplar - Universidade Federal de Minas Gerais. Collaborating Scientist-ACT/Indiana University (grguedes@cedeplar.ufmg.br).
} 


\section{Introduction}

The concept of poverty has received renewed theoretical attention and revision in recent years (SEN; 1985, 1999; KAKWANI; SILBER, 2008a; ALKIRE, 2007). The result has been the emergence of a large literature seeking to identify specific dimensions of poverty that are argued to better capture the complex paths to well-being than existing unidimensional measures of monetary income (BIBI; 2005). However, the literature on Multidimensional Poverty (MDP) presently does a poor job of acknowledging the new challenges that highinformation measures of MDP present to comparative cross-contextual studies of MDP. Using these more refined and data-intensive measures has the potential to reduce the ability to assess and compare poverty across contexts for reasons that range from mundane but important restrictions imposed by data collection and the use of secondary data sources to significant questions about the meaning, relevance, and significance of various dimensions to the overall assessment of poverty across contexts.

Methodologically, differences across the data sets used in studies of MDP - in data collection strategy, rigor, and substantive purpose - create a host of challenges, some of which are error-related, and others of which take on theoretical importance. Based informally upon our own experience in attempting to construct high-information MDP measures for comparative work, the relationship between the number of indicators used in an MDP measure and the availability of that measure (or taking it to the next level, of any measures of a given dimension) in all study areas is a negative one. In short, the likelihood that all relevant measures exist across all comparison contexts is low, and any success in obtaining such a match is due mostly to good fortune rather than systematic coordination.

This creates an unpleasant choice for researchers: forego cross-contextual comparisons of MDP altogether due to a lack of suitable data, or accept a largely unknown degree of bias due to the omission of important variables or dimensions of poverty in one or more sites. Of further concern is the likely possibility that specification and measurement of MDP exhibit a dependency on context rendering cross-contextual comparison difficult even with complete substantive coverage in the data. Much more work is needed to address these issues systematically, particularly the empirical exploration of context-dependence with high-information MDP measures. In this paper, we suggest an approach which represents a compromise between the two options described above.

We address the methodological challenges of comparing high-dimensionality MDP measures across contexts through the identification of multidimensional profiles (so-called "extreme profiles") of poverty and well-being that are determined through a hybrid process that incorporates both data reduction and researcher judgment rather than pure, or naïve, data reduction strategies. Once these extreme profiles exist, we proceed to use fuzzy logic to assign whole or partial membership to each profile for every unit in the sample for each sample of comparative interest (GUEDES et al., 2012). The result is a summary measure of relative well-being that allows for the differential contribution of specific dimensions to the 
overall measure of well-being, both across samples and within samples. Known as vagueness, this property enables us to move from seeking strict cutoff points to identifying gradations of poverty (CHELI, 1995; CHELI; LEMMI, 1995; CHIAPPERO-MARTINETTI, 2004).

We address the theoretical challenge of cross-contextual poverty comparisons using a sequential process in which we sort all available measures of poverty for all contexts of interest into two groups. The first, termed plenary measures, consists of all those measures of any dimension of poverty that are available for all contexts. The second, termed idiomatic measures, consists of all additional measures which are unique to one or more contexts or datasets. We then construct two models of poverty - one which includes only the plenary set and a second which includes both the plenary and the idiomatic indicators. Doing so enables us to identify the effect, within a single context, of moving from a lower-information to a higher-information (site-specific) measure of MDP on overall MDP estimates within that context. While this approach still does not enable us to determine the level of poverty in other contexts under the counterfactual scenario in which these other factors were measured, it does serve as a rudimentary form of sensitivity analysis, capable of alerting researchers to instances in which comparative statements are not supportable, or in need of careful interpretation and scrutiny.

In the analysis that follows, we identify a large set of plenary poverty measures $(P)$ and an equally large set of idiomatic poverty measures (I) for two distinct contexts: - one in Northeastern Thailand and a second in what is known juridically in Brazil as "Legal Amazon," Using a Bayesian approach, we determine that the best fitting models are indeed those containing the most parsimonious set information (in our terminology, the models including variable set "P", the shared measures). Indeed, on a wide range of important and policyrelevant individual measures, the observed relationship is robust to the use of either model $\mathrm{P}+\mathrm{I}$ or model $\mathrm{P}$, suggesting that stronger comparative statements based upon model P may be acceptable, with the standard caveats about unmeasured variables and their complex, qualitative association with the shared indicators. In our example, we find the pattern is consistent for a variety of forms of capitals, ranging from financial to human to social, and for a variety of livelihood activities. The methodology also enables us to quickly assess which factors display a common distribution across contexts and which show a more complex relationship. These results represent a major first step in the unraveling of the relationship between contexts generally and MDP using high-information measures.

Our suggested approach seeks to overcome three important limitations of the current empirical and methodological literature on MDP: 1) we derive our scalar measure of well-being from multi-thematic survey data at the local level, taking a bottom-up like perspective on how families experience deprivation in its multiple dimensions; 2) we focus on the ability of our MDP scalar to be robust to cross-contextual comparisons, and 3) our MDP measure represents an alternative to other proposed scalars at the household/family level, such as the Family Development Index (FDI) or the Human Poverty Index (HPI) (BARROS; CARVALHO; FRANCO, 2003, 2006). Instead of directly adding up variables independently and then assigning a 
weighting scheme, as done in the FDI and HPI indices, we depart from the observed, datadriven multivariate correlation structure of well-being dimensions at the household level to then compare it to a theoretical pattern of well-being. This is key to tackling the problem of how to assign the weighting structure of a summary scalar: instead of creating a post-estimation weight matrix, we use the distance of the multivariate correlation structure from the real data to this theoretical pattern as the weighting scheme.

We begin in Section II by drawing attention to the lack of studies attempting to make quantitative cross-contextual comparisons of MDP using highly dimensional measures and briefly summarizing the literature on MDP assessment. Section III presents our fundamental framework and describes the specific contexts, data, and methods employed. The case studies used in this article are intended to test the robustness of our approach. Thus, we spend more time in this section describing the limitations of current literature on MPDs and how to tackle them by combining different methodologies and theoretical approaches, instead of focusing on a rich description of the Altamira and Nang Rong contexts. Descriptive results are reported in Section IV. We conclude in Section $V$ with a discussion of the future of cross-contextual examinations of MDP, and offer additional practical suggestions to researchers struggling to colonize the middle ground between the rich, single-site examinations and the fairly shallow cross-contextual comparisons that characterize the present state of MDP research.

\section{Background}

\section{Cross-contextual comparisons of multidimensional poverty}

Research identifying independent dimensions of poverty and constructing summary multidimensional poverty (MDP) measures constitutes a large and diverse literature (KAKWANI; SILBER, 2008a; 2008b). Such research benefits from improved depth and breadth of poverty-relevant survey research in recent decades across a wide range of contexts (BETTI et al., 2005). But despite the greater availability of secondary data sources supporting detailed poverty assessments, the MDP literature as a whole displays a reasonably strong bifurcation. On the one hand are numerous studies using large multi-thematic datasets to construct high-information, high-dimensionality poverty measures (e.g. BELLIDO et al., 1998; LUZZI et al., 2008; RAMOS et al., 2008). The chief price paid for such detailed measurement is reduced external generalizability, a limitation acknowledged in many of these single-context studies. At the other extreme are comparative studies of poverty across contexts (e.g. CHEN; RAVALLION, 2007; KRISNAKUMAR, 2008; CHAKRAVARTY; SILBER, 2008; BRADY; FULLERTON; CROSS, 2009). While these also compare poverty multidimensionally across a large sample of contexts (most often, nations), they rely upon a much smaller number of dimensions and specific indicators. The latter are also generally carried out at the macro-level, which while shedding light on certain aspects of the poverty experience may simultaneously leave other aspects of MDP, including cross-scale interactions, hidden or obscure. 
Between these extremes lies a challenging task: developing the methodology and the supporting datasets needed to make cross-contextual comparisons of multidimensional poverty based upon high-information measures of MDP. To better demonstrate this bifurcation in the literature, and the corresponding gap, we undertook a survey of recent empirical studies of MDP. We selected a recent peer-reviewed edited volume (KAKWANI; SILBER, 2008b) and supplemented it with additional articles found using ISI and JSTOR searches on the term "multidimensional poverty". In all, we examined 21 studies between 2004 and 2008 that measure multidimensional poverty using various methodologies latent class, fuzzy set, structural equation, and axiomatic approaches. Figure 1 presents our classification of these studies according to two measures: 1 .) the number of unique indicators used in each MDP measure, and 2.) the number of unique contexts over which the MDP measure was employed. The pattern that emerges is an abundance of low-information, high-comparison studies and many high-information, low comparison studies. There is little activity in the "middle territory" representing high-information and many-comparison studies of MDP (Figure 1). Given the continued importance for both policy and scientific aims of the comparison of poverty - degrees of poverty, shares of the impoverished population, and rankings within and across context - we find this observation about the current literature troubling.

FIGURE 1

Two paths to more information-rich comparisons charted atop cross-classification of recent MDP analyses $(n=21)$

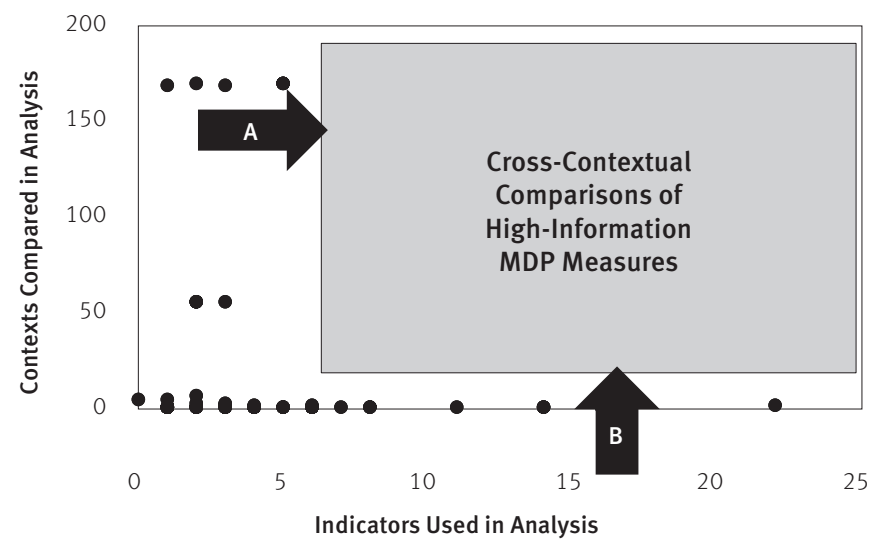

Source: Based on 21 published articles on multidimensional poverty (see references for specific articles).

Superimposed on Figure 1 are two possible paths forward to high-information crosscontextual comparisons of MDP, labeled "A" and "B." Path A corresponds to enlarging the scope of current cross-contextual comparisons to include additional measures. The challenge with this approach is the extreme difficulty in obtaining reliable data on additional dimensions of poverty for the full sample of countries used in such studies. In all likelihood, 
current studies of this type (e.g. CHAKRAVARTY; SILBER, 2008) may already be approaching the upper bound on the number of poverty indicators it is possible to compile for many dozens of countries at around 5 or 6 (typically GPD per capita, expenditure estimates, life expectancy at birth, food expenditure estimates, and literacy rates or school enrollment levels). Path B represents, for us, a more tractable set of challenges. This path corresponds to increasing the number of contexts involved in high-information MDP comparisons. Doing so requires that we address a number of concerns, discussed in detail in the following section.

\section{Theoretical obstacles to cross-contextual comparisons of MDP}

Depth studies help us to understand the dimensional structure of MDP in specific contexts, and provide detailed understanding of its constituent elements. But they provide questionable basis for cross-contextual comparison on a theoretical level. Chief among these is that not all entities that contribute to well-being are A.) monetizable or B.) commensurable. To become monetized, a service, object, or other valued entity must have its value to potential users fixed with reference to a monetary unit of account, such as dollars, pesos, or conch shells. Despite centuries of attempts to fix value in human societies to a single base unit, many valued entities that influence both subjective and objective measures of MDP remain nonmonetized, for example: a.) the value of child care and housework when provided by family members (ZELIZER, 1989; 1997; CHASE-DUNN; KAWANO; BREWER, 2000), b.) the value of land that has been passed down over generations (CARNEIRO 2001; VANWEY; CEBULKO, 2007; GUEDES; QUEIROZ, 2008; GUEDES; QUEIROZ; VANWEY, 2009; LUDEWIGS et al., 2009; VANWEY; GUEDES; D’ANTONA, 2011), or c.) the monetary value of scholarly advice and editorial services rendered between colleagues (PRENDERGAST; STOLL, 1996). Even if the monetary value of such entities can be determined in principle, there are several reasons why researchers should be cautious in doing so. In cases like those above, humans generally are not simply lacking the ability to monetize a good or service, but actively resisting such pecuniary valuation in deference to cultural norms, mores, and social institutional restrictions that researchers are wise (if not ethically bound) to honor.

The challenge imposed by monetization and commensurability is especially important when one wants to study material rural well-being. In rural settings, the possession of money may be of little importance for certain goods and services, for whose markets are imperfect or nonexistent. Reciprocity rules are a good example of quasi-economic institutions that promote well-being among rural households without the need to assess traditional market for tangibles, such as food, clothing or farm work (BEBBINGTON, 1999; DE SHERBININ et al., 2008). Place-specific capital is also ignored as an important component of well-being in most MDP measures, such as HDI, which focus exclusively on formal educational attainment. In this regard, an urban-bias among current aggregate MDP indices seems to prevail. 
Just as important, humans also continue to stubbornly impose a complex web of noneconomic valuations and concerns overtop of exchange transactions. These protected values (BARON; SPRANCA, 1997) restrict the range of goods and services that are commensurable, and raise concerns about how to quantify values that humans themselves actively resist quantifying. These concerns are both ethical and pragmatic. Ethically, if a respondent states that no monetary price can or should be affixed to vital services rendered by friends and family, it may not be justifiable for the researcher to assign monetary value to them anyway. Pragmatically, in avoiding attaching an arbitrary monetary value to various constituent elements of well-being, we encounter commensurability in a different form. In a specific context like Altamira, Brazil, for example, land is valued based upon many complex factors, only some of which are directly monetizable, and to complicate matters further, land is not bought and sold with a regularity sufficient to establish a reliable price standard for land. Yet the natural capital embodied in the land is a central component of household well-being in this context (GUEDES et al., 2012). Thus, the practical challenge is how to include land in a measure of MDP along with per capita income, for example, without forcing the value and contribution of the former to be artificially computed in the units of the latter. One approach is to explicitly reject single-unit calculations of wealth. Such approaches, while avoiding the need to make financial capital and natural capital directly commensurable, are limited by the difficulty in making overall comparisons across units of analysis when each unit may have multiple differing "scores" for poverty - one for each class of valued entities assessed.

An alternative approach is to consider each indicator as having an underlying distribution of some sort and calculate the position in that distribution for each subject. By "adding up" the relative positions of subjects on each dimension, one comes closer to a measure of MDP that assesses the value of a bundle of goods, capitals, and other valued entities that are not strictly commensurable. This approach has been proposed by Brazilian researchers at the IPEA Institute for Applied Economic Research (IPEA). Both the Family Development Index (FDI) and the Human Poverty Index (HPI) render summary multidimensional scalars of poverty at the family/household level that are easily collapsed up and down to different levels of interest (BARROS; CARVALHO; FRANCO, 2003, 2006). Although representing an important advance to previous multidimensional indices, such as the HDI (UNDP, 1990), such an approach still fails to consider the interactive potential of a household possessing sufficient amounts of two capitals, such as land and labor, that provide much greater levels of wealth and wellbeing in conjunction with each other than separately. That is, the weighting scheme applied to these scalars lacks the ability to capture the joint functioning of multiple dimensions that are frequently idiosyncratic to each household.

Our answer to this problem is to utilize Grade of Membership (GoM) modeling, which belongs to a class of latent class models which can simultaneously consider the relative position of a household on each distribution and assign that household an overall score 
of belonging to each of a set of "extreme profiles" measuring MDP. These profiles articulate the specific responses given by a hypothetical model household that would be considered as impoverished or as wealthy as possible. Our resulting measure, the distance between a household and each extreme profile, represents not an absolute measure of total assets, well-being, or poverty, but rather a relative measure which can be interpreted as a household's (or other unit's) location on a distribution of distances from "maximal wealth" or "maximal poverty." Importantly, the vagueness of a fuzzy approach to poverty measurement ensures that the relative contribution of each separate constituent member is permitted to vary across households and across contexts. If land ownership, for example, represents a different relationship to total MPD in two different research locations, this method permits the accurate estimation of the contribution of land to MDP in each location, while maintaining overall comparability. In the next section, we describe this approach in greater detail.

In addition to incorporating a flexible weighting scheme, allowing for the structure (composition) of the household's portfolio of capitals in each context, our tentative methodology seeks to address an "urban bias" present in other MDP measures, basing our reference group (the maximum well-being profile) on solid theoretical frameworks, such as the livelihood strategies approach as well as the capital portfolios' perspective. This way, an important part of the methodological proposition relies on identifying what defines a reference group. As a heads-up, we alert for the need to adapt the theoretical comparison group in urban contexts, for instance, when some of the capitals may reach high levels of incommensurability or contextual irrelevance.

\section{Data and methods}

\section{Data and context}

We selected two sites at different stages of transitioning from frontier to established agricultural regions to illustrate our approach (VANWEY; HULL; GUEDES, 2013). Nang Rong District, Thailand, began to witness dramatic population growth attributable to an influx of frontier settlers in the 1950s. Altamira, located in the Brazilian state of Para on the threshold of the Amazon, also experienced a large influx of settlers following the opening of the TransAmazon highway in the 1970s. In both cases, extensive field work has been paired with longitudinal data collections to produce a detailed picture of relative household poverty over time (for detailed descriptions of methodology, see RINDFUSS; ENTWISLE; WALSH, 2009 for Nang Rong and BRONDÍZIO et al., 2002; VANWEY; D’ANTONA; BRONDIZIO, 2007; VANWEY; GUEDES; D’ANTONA, 2011; GUEDES et al., 2012 for Altamira). As a result, we have two socioeconomic survey instruments which have undergone extensive field-testing over many years to improve the validity of individual items and the overall breadth of domains represented in the questions. 
In our Altamira study site, 402 households and farm properties were sampled. The stratified sample of farm units by cohort of settlement is representative of the farm units in the region. Both heads of the households were interviewed, along with any other females aged fifteen and over. Males responded to an economic and land use questionnaire, while females answered questionnaires covering family sociodemography, reproductive history, and the use of contraceptive methods. For poverty measures using multidimensional variables, we restricted our sample to the 1997/1998 owners who had complete information on income and additional selected characteristics ( $N=307$ observations).

In our Nang Rong study area, we use data collected during the year 2000 nonagricultural season. A complete census was conducted in 92 villages. Household interviews were conducted with key informants on a wide range of subjects, including demography, life histories for some household members, migration histories, economic measures, agricultural production, and land use. Community-level interviews were carried out with key informants in every village in the district, which were used to construct some measures in the present analysis. In total, 8,583 out of 8,638 households provided usable responses for this analysis.

\section{Selecting indicators}

Recent research suggests that a hybrid approach to constructing MDP measures involving both systematic data reduction and expert judgment can be as effective as unsupervised methods alone (ALKIRE, 2007). We use a hybrid approach focused on indicators rather than dimensions in order to remove measurement errors that may be introduced by differing linkages between indicators and dimensions. To do so, we begin by grouping all indicators from each dataset into two categories. The first, termed plenary, or shared, poverty measures (P), includes all poverty indicators existing in all datasets which also have relevance in all contexts. The second, termed idiomatic, or unique, poverty measures (I), are all other poverty indicators of interest which are not available for all datasets or relevant in all contexts.

Boxes 1 and 2 list the plenary and idiomatic indicators used in this analysis. Box 1 is a sideby-side comparison of indicators judged to be similar enough to allow for a direct comparison across study sites. Box 2 lists all indicators for which no corresponding measure is available in the other dataset. The existence of such idiomatic measures is likely to be common when working secondarily with two or more data sets collected for different purposes in different contexts. While it is extremely important that researchers continue to press for new multicontext, multi-thematic datasets, the abundance of single-site multithematic datasets makes the development of a methodology capable of supporting the measurement and analysis of MDP with existing data an important goal. 


\section{BOX 1}

Plenary measures of multidimensional poverty (model P) used for Nang Rang, Thailand (2000) and Altamira, Brazil (1997/98)

\begin{tabular}{|c|c|c|}
\hline Level & Measure: Nang Rong & Measure: Altamira \\
\hline Ordinal & $\begin{array}{l}\text { Educational attainment of the household } \\
\text { head }\end{array}$ & $\begin{array}{l}\text { Educational attainment of the household } \\
\text { head }\end{array}$ \\
\hline Dichotomous & Sex of the household head & Sex of the household head \\
\hline Dichotomous & Child with parent absent in the household & Child with parent absent in the household \\
\hline Dichotomous & Multiple household on the same property & Multiple household on the same property \\
\hline Ordinal & $\begin{array}{l}\text { Demographic dependency ratio of the } \\
\text { household }\end{array}$ & $\begin{array}{l}\text { Demographic dependency ratio of the } \\
\text { household }\end{array}$ \\
\hline Dichotomous & Household has at least one refrigerator? & Household has at least one refrigerator? \\
\hline Dichotomous & Household has at least one color tv? & Household has at least one color tv? \\
\hline Dichotomous & $\begin{array}{l}\text { Household has at least one sewing } \\
\text { machine? }\end{array}$ & $\begin{array}{l}\text { Household has at least one sewing } \\
\text { machine? }\end{array}$ \\
\hline Dichotomous & Household has at least one satellite dish? & Household has at least one satellite dish? \\
\hline Dichotomous & $\begin{array}{l}\text { Does the household operate shop, stall, or } \\
\text { peddlers car? }\end{array}$ & $\begin{array}{l}\text { Does the household operate a small } \\
\text { business? }\end{array}$ \\
\hline Dichotomous & $\begin{array}{l}\text { Does the household use herbicide in one or } \\
\text { more plot? }\end{array}$ & Does the household use herbicide? \\
\hline Dichotomous & $\begin{array}{l}\text { Does the household use fertilizer in one or } \\
\text { more plot? }\end{array}$ & Does the household use chemical fertilizer? \\
\hline Dichotomous & $\begin{array}{l}\text { Does the household use pesticide in one or } \\
\text { more plot? }\end{array}$ & Does the household use pesticide? \\
\hline Dichotomous & $\begin{array}{l}\text { Does the household use irrigation/water } \\
\text { diversion in one or more plot? }\end{array}$ & $\begin{array}{l}\text { Does the household use irrigation/water } \\
\text { diversion? }\end{array}$ \\
\hline Dichotomous & $\begin{array}{l}\text { Do } 1 \text { or more migrants remit cash or goods } \\
\text { to the household? }\end{array}$ & $\begin{array}{l}\text { Did at least one migrant remit money or } \\
\text { good to the household? }\end{array}$ \\
\hline Ordinal & $\begin{array}{l}\text { Total land used for agriculture in the } \\
\text { previous year (hectares) }\end{array}$ & $\begin{array}{l}\text { Proportion of the property used for } \\
\text { agriculture (pasture, perennial, annual, } \\
\text { orchard) (quintiles) }\end{array}$ \\
\hline Ordinal & Number of plots owned by the household & $\begin{array}{l}\text { Number of rural properties owned by the } \\
\text { household }\end{array}$ \\
\hline Ordinal & $\begin{array}{l}\text { Per capita household income (ag prod+ag } \\
\text { wage+other wage) in US } 2000 \text { dollars } \\
\text { (quintiles) }\end{array}$ & $\begin{array}{l}\text { Per capital household income (agriculture, } \\
\text { wage, pension) (quintiles) }\end{array}$ \\
\hline Dichotomous & $\begin{array}{l}\text { Household used family labor (rice, cassava, } \\
\text { sugar) in the last season? }\end{array}$ & Does the household use family labor? \\
\hline Dichotomous & $\begin{array}{l}\text { Household used non-monetized labor (rice, } \\
\text { cassava, sugar) in the last season? }\end{array}$ & $\begin{array}{l}\text { Does the household use sharecropper } \\
\text { labor? }\end{array}$ \\
\hline Dichotomous & $\begin{array}{l}\text { Household used monetized labor (rice, } \\
\text { cassava, sugar) in the last season? }\end{array}$ & Does the household use paid labor? \\
\hline Ordinal & $\begin{array}{l}\text { Number of years that the village has had } \\
\text { electricity }\end{array}$ & Type of power supply \\
\hline Dichotomous & Household has piped water indoors? & Does the household have piped water? \\
\hline Ordinal & $\begin{array}{l}\text { Values of all livestock in } 2000 \text { US dollars } \\
\text { (quintiles) }\end{array}$ & $\begin{array}{l}\text { Amount of cattle owned by the household } \\
\text { (quintiles) }\end{array}$ \\
\hline Dichotomous & $\begin{array}{l}\text { Current household members work outside } \\
\text { the village? }\end{array}$ & $\begin{array}{l}\text { Does anyone in the household have off-farm } \\
\text { employment? }\end{array}$ \\
\hline
\end{tabular}

Source: Based on Altamira Survey Data (1997/98); Nang Rong Survey Data (2000). 
BOX 2

Idiomatic measures of poverty (added to model P + I) used for Nang Rang, Thailand (2000) and Altamira, Brazil (1997/98)

\begin{tabular}{|c|c|c|c|}
\hline Level & Nang Rong idiomatic measures & Level & Altamira idiomatic measures \\
\hline Dichotomous & HH speaks minority language & Dichotomous & Household received lot from INCRA \\
\hline Ordinal & Housing quality & Dichotomous & $\begin{array}{l}\mathrm{HH} \text { has other relatives or friends } \\
\text { living in region }\end{array}$ \\
\hline Ordinal & Type of windows in house & Dichotomous & $\begin{array}{l}\text { HH has a member living in the urban } \\
\text { study area }\end{array}$ \\
\hline Ordinal & Type of cooking fuel used & Ordinal & $\begin{array}{l}\text { Quintiles of per capita monetized } \\
\text { production for self-consumption }\end{array}$ \\
\hline Ordinal & Degree of secure title to home & Ordinal & Proportion of the lot in pasture \\
\hline Dichotomous & HH owns telephone & Ordinal & Proportion of the lot in forest \\
\hline Dichotomous & HH owns computer & Ordinal & Proportion of the lot in perennials \\
\hline Dichotomous & HH owns microwave & Ordinal & Proportion of the lot in annuals \\
\hline Dichotomous & HH owns washing machine & Dichotomous & $\begin{array}{l}\text { Production technology based on } \\
\text { animal draft? }\end{array}$ \\
\hline Dichotomous & HH owns air conditioner & Dichotomous & $\begin{array}{l}\text { Manual-based production } \\
\text { technology? }\end{array}$ \\
\hline Dichotomous & HH owns car & Dichotomous & $\begin{array}{l}\text { Motor-based production } \\
\text { technology? }\end{array}$ \\
\hline Dichotomous & HH owns VCR & Dichotomous & Accessibility during rainy seasons? \\
\hline Dichotomous & HH owns mobile phone & Dichotomous & Position of house on the lot \\
\hline Dichotomous & HH owns farm engine & Ordinal & Number of credits ever received \\
\hline Dichotomous & HH owns bicycle & Dichotomous & $\begin{array}{l}\text { Does HH participate in formal/ } \\
\text { informal agricultural organization? }\end{array}$ \\
\hline Dichotomous & HH owns large motorcycle & Ordinal & Type of material the wall is made of \\
\hline Dichotomous & HH owns small motorcycle & Ordinal & Type of material the floor is made of \\
\hline Dichotomous & HH owns large truck & Ordinal & $\begin{array}{l}\text { Type of material the roof/cover is } \\
\text { made of }\end{array}$ \\
\hline Dichotomous & HH owns pickup truck & Ordinal & Location of the bathroom \\
\hline Dichotomous & HH does silk weaving for sale & Ordinal & Type of drain/sewage system \\
\hline Dichotomous & $\mathrm{HH}$ raises silk worms for sale & Dichotomous & $\begin{array}{l}\text { Well-off position upon arrival in the } \\
\text { region }\end{array}$ \\
\hline Dichotomous & HH weaves cloth for sale & Ordinal & Number of other properties \\
\hline Dichotomous & HH makes charcoal for sale & Ordinal & $\begin{array}{l}\text { Number of assets household } \\
\text { currently owns }\end{array}$ \\
\hline Dichotomous & HH gathers firewood for sale & & \\
\hline Ordinal & Total income from remittances & & \\
\hline Dichotomous & Migrant remitted clothing & & \\
\hline Dichotomous & Migrant remitted food & & \\
\hline Dichotomous & Migrant remitted household goods & & \\
\hline Dichotomous & Migrant remitted vehicle & & \\
\hline Dichotomous & HH owns large tractor & & \\
\hline Dichotomous & HH owns large tiller & & \\
\hline Dichotomous & HH owns rice thresher & & \\
\hline
\end{tabular}

Source: Based on Altamira Survey Data (1997/98); Nang Rong Survey Data (2000) 


\section{General comparative framework}

We utilize a fuzzy approach known as Grade of Membership (GoM), described in detail in the next section, combined with traditional axiomatic measures of poverty (Foster-GreerThorbecke indicators), to create a summary MDP measure. We estimate two models, first with only the plenary poverty measures $(P)$, and second incorporating variables from both the plenary and the idiomatic sets of indicators $(P+I)$. This procedure allows us to compare MDP between contexts using the plenary measures common to both contexts, while enabling us to determine the effect of excluding the idiomatic poverty measures from the first model. The latter provides an answer to the question of what happens to MDP within context as the set of indicators used in measurement is altered, essentially a sensitivity test that conditions the nature, strength, and generalizability of the conclusions drawn from the first set of crosscontextual comparisons. This comparative framework is summarized graphically in Figure 2.

FIGURE 2

Framework for comparison of multidimensional poverty across contexts

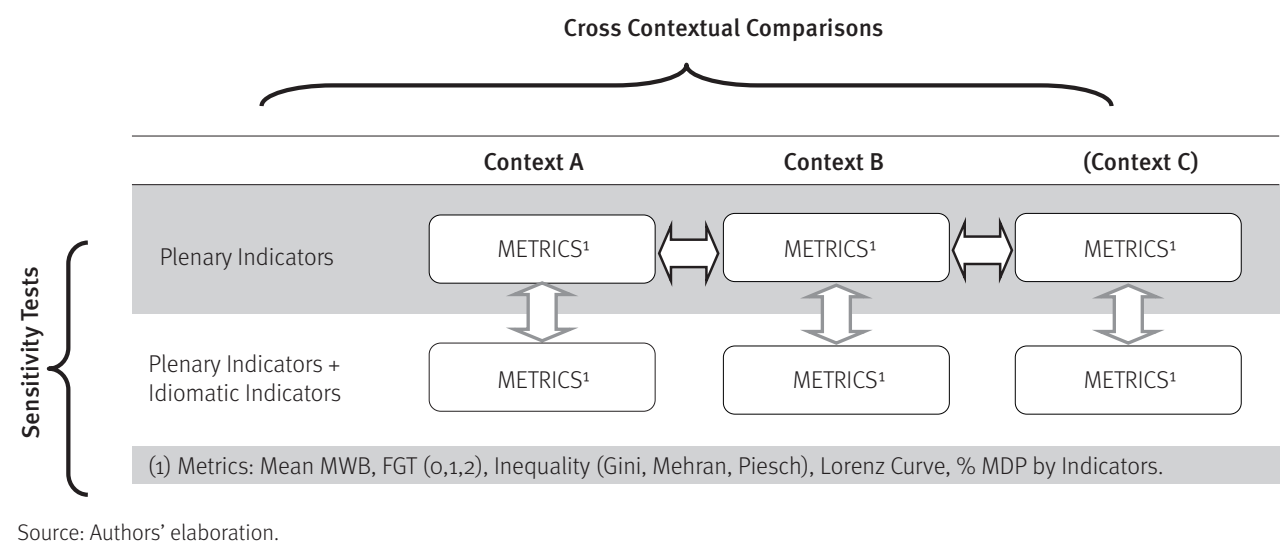

We expect that in many contexts the results of the first $(P)$ and second $(P+I)$ models will diverge in non-trivial ways. This is an important consequence of using this approach. When a researcher requires the most accurate measurement possible of poverty in a single context, numerous existing approaches may prove adequate. But if the aim is to understand the interaction of context and poverty measurement, then our simple heuristic may be of great value in helping researchers to identify potentially invalid comparisons. In the absence of a single, common metric for the determination of all value, the best one can do is compare those things that are common first, and then attempt to gauge the impact of adding in the rest.

\section{Grade of Membership modeling applied to multidimensional scalars}

We utilize Grade of Membership (GoM) modeling, a fuzzy logic methodology (MANTON; WOODBURY; TOLLEY, 1994), to generate a single continuous measure of the extent to 
which a household is multidimensionally poor, while avoiding the direct commensuration of various household assets. To do this, we compare empirical profiles of each household in each sample to theoretical profiles of maximal well-being, generating a measure of the distance between the household's lived experience and a sociological ideal type of maximum well-being (GUEDES; CARMO, 2012; GUEDES et al., 2012). Following Garcia; Soares-Filho; Sawyer (2007) we call this approach the hierarchical latent scalar approach, differing from a traditional exploratory latent class approach where profiles of well-being would freely arise from empirical correlation structure of the data.

Instead of using initial random probability matrices for the locational parameters estimation within GoM environment, as done is most of the applied literature (SAWYER; LEITE, ALEXANDRINO, 2002; GUEDES; QUEIROZ; VANWEY, 2009), we define a model with two extreme profiles, $K=2$, where for each variable, $j$, in profile $k=2$, the category representing the most well-off, will receive probability equal to one $\left(\lambda_{\mathrm{kjl}}=1,000\right)$, and zero for the others. For profile $k=1$ the opposite is done, that is, for the least well-off category of a variable $j$, the probability equals one and zero for all the others. With this strategy, the fuzzy partition parameter $\left(\mathrm{g}_{\mathrm{ik}=2}\right.$, or simply $g_{\mathrm{i} 2}$ ) measures the observed multidimensional intensity of well-being for each individual in the sample. An example of such a matrix is presented in Table 1. Once the fuzzy partition $\mathrm{g}_{\mathrm{i} 2}$ is estimated, we use it as the empirical function of multidimensional well-being. We use this function to estimate various traditional poverty and inequality indices, which hold the same axiomatic properties as the original measures, but are based on a multidimensional scalar rather than monetary income.

TABLE 1

Exemplifying the hierarchical latent scalar approach for multidimensional well-being estimation informed hierarchical latent probability matrix $\left(\lambda_{\mathrm{kjl}}\right)$ using educational attainment of household head Nang Rong, Thailand - 2000

\begin{tabular}{lccc}
\hline \multicolumn{1}{c}{ Variable } & $\begin{array}{c}\text { Unconditional } \\
\text { Probability }\end{array}$ & Hierarchical Latent Probability $\left(\lambda_{\text {kj }}\right)$ \\
\hline $\begin{array}{lcc}\text { Educational Attainment of the Household Head } \\
\text { (Nang Rong, Thailand) }\end{array}$ & $\begin{array}{c}\text { Sample } \\
\text { Population }\end{array}$ & $\mathrm{K}=1$ & $\mathrm{~K}=2$ \\
\hline Illiterate & 0.8107 & 1.0000 & 0.0000 \\
1 to 4 & 0.1131 & 0.0000 & 0.0000 \\
or more & 0.0762 & 0.0000 & 1.0000 \\
\hline
\end{tabular}

Source: Based on Nang Rong Survey Data (2000).

\section{Multidimensional poverty and inequality assessment}

We use three summary measures of poverty and two measures of inequality in order to assess differences between models $\mathrm{P}$ and $\mathrm{P}+\mathrm{I}$. FGT (Foster-Greer-Thorbecke) metrics correspond to a set of indices based on headcounts and poverty gaps. These indices are widely applied in poverty studies and used to measure several aspects of poverty such as proportion, intensity and severity (STEWART, 2006). Instead of substitutes, they can be seen as complementary, since they respond to different aspects of poverty (FOSTER; GREER; 
TORBECKE, 1984; HOFFMANN, 1998). The three FGT measures used are: the headcount ratio $(\mathrm{HC})$, the poverty gap index (PGI), and the squared poverty gap index (PGI). FGT measures are traditionally used to estimate poverty based on per capita income level, but we extend them to our scalar measure of multidimensional well-being in order to assess both the change in MDP levels using model $\mathrm{P}$ and $\mathrm{P}+\mathrm{I}$ and the distribution of composite well-being across a variety of individual indicators.

We apply two of the most common income inequality measures in the empirical literature: Gini and $L$ Theil. Gini coefficient can be derived from the synthetic well-being distribution or from the Lorenz Curve. Gini coefficient graphically represents the increase in the cumulated proportion of income due to the cumulated proportion of population over the i-th person. The closer to unity, the higher the inequality of the population (DORFMAN, 1979). Interpretation of $L$ Theil is similar to the Gini coefficient, although it has a wider range of scalar variation and is bound to 0 and infinity. The closer to zero, the lower the inequality is. Different from Gini, $\mathrm{L}$ Theil is not applicable to households with no income (HOFFMANN, 1998).

\section{Plotting proportions of poor across the range of key variables}

Once the summary MDP measures are calculated for models $\mathrm{P}$ and $\mathrm{P}+\mathrm{l}$, we plot the proportion of households in each sample that are considered multidimensionally poor over a ranges of individual indictors. Doing so enables us to quickly assess changes in the relationship between overall MDP and individual components for multiple contexts when one moves from the ideal site-specific model $(\mathrm{P}+\mathrm{l})$ to one appropriate for cross-contextual comparisons $(P)$. This lets us answer the question of how the relationship between the individual indicator and the overall MDP measure changes when the total amount of information in the model is altered. To guide interpretation, we introduce a three-part heuristic, summarized in Figure 3. The first possibility is no observed change in the level or distribution of poverty across a variable's range comparing models $\mathrm{P}$ and $\mathrm{P}+\mathrm{I}$. This indicates that inclusion of additional variables in model $\mathrm{P}+\mathrm{l}$ has no impact. The second scenario is a change in the levels of poverty across different levels of a variable, without a change to the functional form of the distribution. This implies that it is defensible to talk about the patterned relationship between MDP and that variable in a comparative sense using either model, so long as numerical comparisons of poverty are avoided. The third class consists of variables for which both the level and the overall shape of the distribution of MDP across levels of a given variable change markedly between models $\mathrm{P}$ and $\mathrm{P}+\mathrm{I}$. For this group, the extra dimensions and information included in model $\mathrm{P}+\mathrm{I}$ are highly correlated with other variables in model P, introducing bias when they are omitted and fundamentally altering the conclusions reached about the relationship between that variable and overall MDP.

This process yields a determination about which of these three conditions holds for each key variable. If the first holds, then one can generalize about both levels and patterns for 
that variable across contexts. If only the second is true, some generalizations across context still make sense, but only those that pertain to general patterns. Generalizations about the level of poverty in this case are unreliable because the estimates of poverty levels are highly sensitive to the inclusion or exclusion of factors that are highly specific to that single context. If the third obtains, no generalizations are warranted, as both the level and the pattern of relationships between specific variables. In this case, additional qualitative investigation is called for to understand how the intersection of dimensions affects the overall poverty experience (LAWSON; MCCKAY; OKIDI, 2006).

FIGURE 3

Generalized patterns of response to inclusion of idiomatic poverty measures

Measures

1) No change

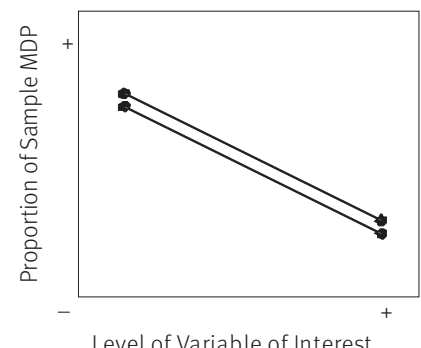

Level of Variable of Interest
2) Change in Level

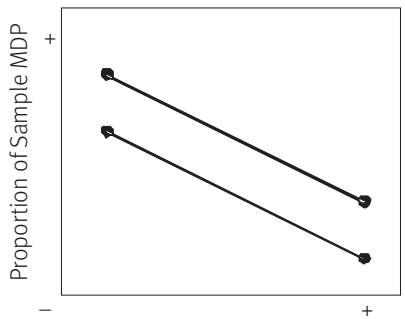

Level of Variable of Interest
3) Change in Pattern

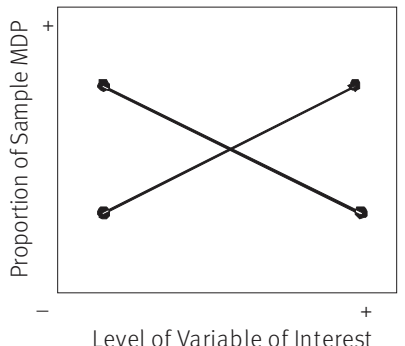

Source: Authors' elaboration

\section{Results}

Model fit

Table 2 reports fit statistics for each model. It is important that we confirm the improved fit of model P for both contexts according to the AIC. Decreased model fit in the higher-information model indicates that idiomatic information for each context is not adding valuable additional explanatory power to the selected indicators available in both contexts (that is, in model P). In substantive terms, model $\mathrm{P}+\mathrm{I}$ represents a redundant set of estimates in comparison with model $P$, adding an excessive amount of information to the core of compared measures. This redundancy arises from two main sources of noise: a) imperfect proxies for a specific dimension; b) the existence of a more complex correlation structure between the shared and unique measures within context that is not being fully represented by the empirical measures, requiring qualitative scrutiny. To better understand the numerical nature of this degradation as additional information is added, we look at what happens to the estimates for each of the FGT measures and the two inequality measures. 
TABLE 2

Fit statistics for models P and P + I for Nang Rong, Thailand (2000) and Altamira, Brazil (1997/98)

\begin{tabular}{|c|c|c|c|c|c|c|c|c|c|}
\hline Model & & $\mathrm{K}$ & $\mathbf{N}$ & $\mathrm{L}$ & $\lambda$ & G & $\mathbf{P}$ & $\mathrm{LN}(\mathrm{L})$ & AIC \\
\hline \multicolumn{10}{|c|}{ Altamira, Brazil, 1997/98 } \\
\hline $\mathbf{P}$ & & 2 & 307 & 52 & 104 & 614 & 718 & -51567 & 104570 \\
\hline$P+I$ & & 2 & 307 & 121 & 242 & 614 & 856 & -143704 & 289120 \\
\hline \multicolumn{10}{|c|}{ Nang Rong, Thailand, 2000} \\
\hline $\mathbf{P}$ & 2 & & 8583 & 50 & 100 & 17166 & 17266 & $-1 \mathrm{E}+06$ & 2889767 \\
\hline$P+I$ & 2 & & 8583 & 124 & 248 & 17166 & 17414 & $-2 E+06$ & 4352820 \\
\hline
\end{tabular}

Source: Based on Altamira Survey Data (1997/98); Nang Rong Survey Data (2000).

\section{Comparing levels of MDP and inequality}

Figure 4 presents estimates for the FGT measures by model and context. In Nang Rong, head count poverty estimates jumps from 20 percent to 23 percent when one moves from the idiomatic to the plenary model. Despite the change in absolute terms, the proportion of poor is quite similar for both models. In Altamira, the same jump is more substantial from 22 to 34 percent, implying that idiomatic measures may have a greater influence on estimates of poverty in Altamira than in Nang Rong. The same pattern is seen with the PGI and squared-PGI. As previously suggested, the sensitivity to levels and patterns may be reflective of various sources of noise: a) imperfect proxies, b) more complex correlational structure of dimensions than the one expressed by the survey-based measures. A similar result obtains for the Gini and $L$ Theil measures of inequality, except that the greater increase from model $\mathrm{P}+\mathrm{I}$ to model $\mathrm{P}$ occurs in Nang Rong, where inequality on the Gini measures jumps from 0.24 to 0.33 when one moves to the lower information model. The corresponding jump in Altamira is from 0.22 to 0.26 .

Based on the AIC coupled with results from Figure 4 and Figure 5, we can conclude that use of model $\mathrm{P}$ will lead to a more efficient, parsimonious, and conservative picture of poverty and inequality, since it satisfactorily summarizes the structure of well-being with the shared measures, at the same time that it avoids bias from limited information about the source of idiomatic noise. The sensitivity test supports our stated intention of determining whether any conclusions about poverty and its association with specific factors of interest may be warranted across multiple contexts. The potential for interaction between context-specific indicators of poverty and our overall measure renders the comparison of models containing substantially different idiomatic measures potentially suspect, a classic apples-to-oranges comparison if ever there was one.

Despite the support for the plenary model according to the AIC statistics, we want to assure that the overall fit holds for specific indicators when comparing models $\mathrm{P}$ and $\mathrm{P}+\mathrm{I}$. AIC is as good as the quality of information provided to the model. If proxies are limited, so will conclusions from AIC be limited. We seek, therefore, to determine whether any comparative statements based upon an interpretation of model P might be warranted. We do so by comparing specific patterns of change in poverty by levels of selected indicators as we move from model $\mathrm{P}$ to model $\mathrm{P}+\mathrm{I}$. 
FIGURE 4

Comparison of multiple poverty measures across contexts and models - multidimensional FGT measures for Nang Rong, Thailand (2000) and Altamira, Brazil (1997/98)

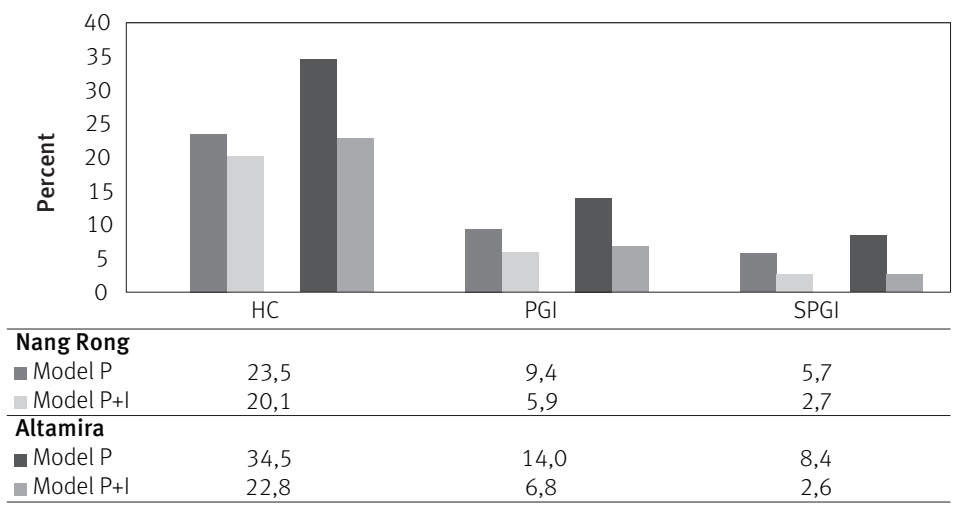

Source: Based on Altamira Survey Data (1997/98); Nang Rong Survey Data (2000).

FIGURE 5

Comparison of multiple inequality measures across contexts and models - multidimensional inequality indices for Nang Rong, Thailand (2000) and Altamira, Brazil (1997/98)

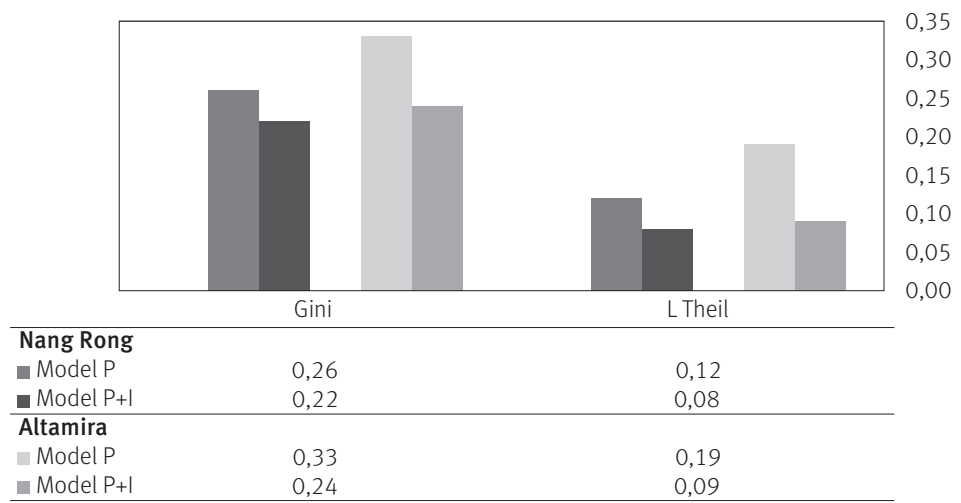

Source: Based on Altamira Survey Data (1997/98); Nang Rong Survey Data (2000).

\section{Distributions of MDP over the range of select variables}

Figure 6 presents the distribution of our summary MDP measure across a set of five variables selected for their correspondence to the five capitals identified in the sustainable livelihoods framework - financial capital, physical capital, natural capital, social capital, and human capital (BEBBINGTON, 1997; 1999; CARNEY, 1998; DE SHERBININ et al., 2008). These selected variables enable us to take a rapid summary view across each of these five capitals in two contexts and observe the extent to which the choice of model impacts the observed relationship. Generally Figure 6 provides little support for the conclusion that interpreting the lower-information model (gray lines) would result in a 
different set of interpretations from those obtained using the optimal model (black lines). In some instances, as with natural capital measure in Altamira, we do observe a shift in the estimated level of poverty for each quintile group. But the shift occurs across the board and appears to show no more complicated interaction with this measure of area used for agriculture.

The observation that the functional forms of MDP distributions across variables are consistent between models permits us to interpret these patterns substantively. One piece of contextual information that is extremely relevant for interpreting these results in both sites is that the Nang Rong study site occupies a later stage of a general frontier transition than the Altamira research area (VANWEY; HULL; GUEDES, 2013). Interpreting the present results in light of this observation, natural capital displays a simple monotonic positive relationship with well-being (proxied by area in agriculture). This is consistent with a broad literature citing the significance of natural capital in frontier contexts. Physical capital as proxied by irrigation investments shows a similar relationship, with households that possess irrigation equipment showing lower levels of MDP. Moving to social capital as proxied by the number of migrants remitting cash or goods, however, we observe another interesting difference. While households with more migrants display a greater level of multidimensional well-being in Nang Rong, those households in Altamira with the greatest level of well-being occupy an intermediate set of values on the number of remitting migrants. The data suggest important differences in the significance and success of migration as a strategy for poverty alleviation in these two sites, with Nang Rong presenting a more mature and integrated frontier with greater opportunities for migrants. Discrepant patterns are likewise evident across sites for financial capital (per capita income) and human capital (education attainment of household head). While each incremental increase in the quintile of per capita income is associated with a reduction in the proportion poor for Nang Rong, in Altamira the association takes a curvilinear form. Among households in the lowest quintile of financial capital we observe lower overall levels of MDP than for the next two higher quintiles. This observation again speaks to the youth of this frontier context, in which it is possible for households to achieve well-being in the absence of large stocks of financial capital.

We can conduct the same sort of analysis using a second set of measures that roughly proxy a variety of significant livelihood strategies in both contexts. As with Figure 6, we are limited to the plenary set of indicators. From this set, we selected four theoretically interesting livelihood practices and one additional measure that proxies the stage of the household lifecycle (MCCRAKEN et al., 2002). These four livelihood practices - off-farm labor, operation of a small business or market stall, livestock raising (large stock like cattle), and participation in the monetized labor exchange economy rather than relying upon in-kind exchange - represent prominent (and often interlocking) strands in complex and diverse livelihoods in both the Thailand and Brazil study site, but are not exhaustive. In Nang Rong, perhaps even more than Altamira, households engage in a 
wide array of occupations, pursuits, and enterprises directed at obtaining greater well-being (THOMAS, 1988; GRANDSTAFF, 1992; HULL, 2007). Gaining a complete picture of household livelihoods is challenging because of the temporary and fleeting nature of some livelihood practices (RIGG, 2003), but where the impact of livelihood diversity on development has been examined, the effect of greater diversity has been positive in contexts similar to Altamira and Nang Rong that are or were historically agricultural (ELLIS, 1998). The long-term investment required to successfully incorporate these practices in a household livelihood strategy and the involvement of multiple broad capital classes in their execution makes them useful as indicators. As one example, the use of paid labor for the rice harvest in Nang Rong requires numerous adjustments by households who must acquire sufficient cash for payments, setting them on a very different path of household labor allocation, economic activity, and livelihood compatibility than those exchanging labor in kind (HULL, 2010).

FIGURE 6

Proportion MDP over range of key capitals, plotted by context and model (gray $=P$, black $=P+l$ ) - Nang Rong, Thailand (2000) and Altamira, Brazil (1997/98)

Nang Rong, Thailand

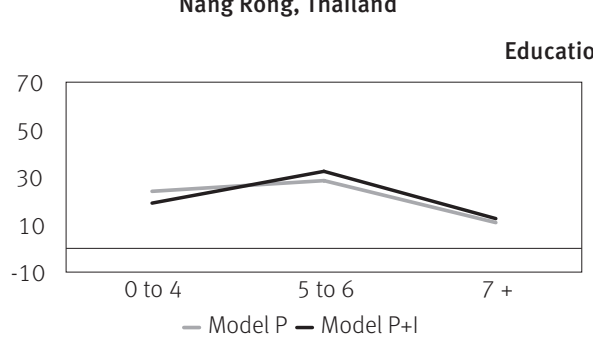

Altamira, Brazil

Altamira, Brazil

ducation of Household Head

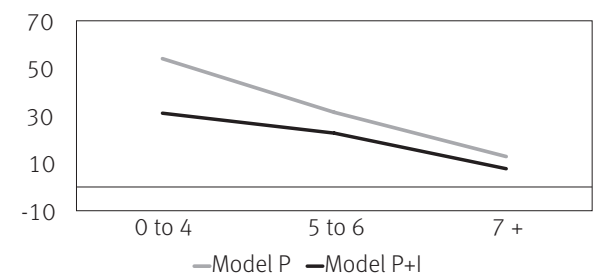

Household Per Capita Income
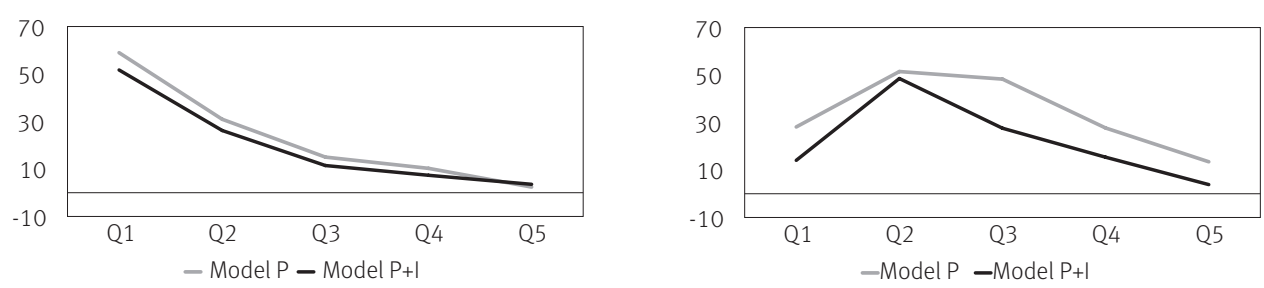

Number of Remitters
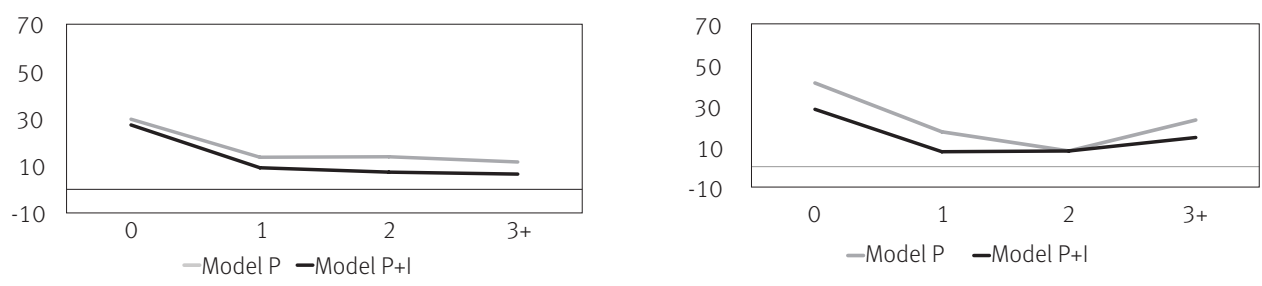

(continue) 
(conclusion)

Irrigation/Water Diversion
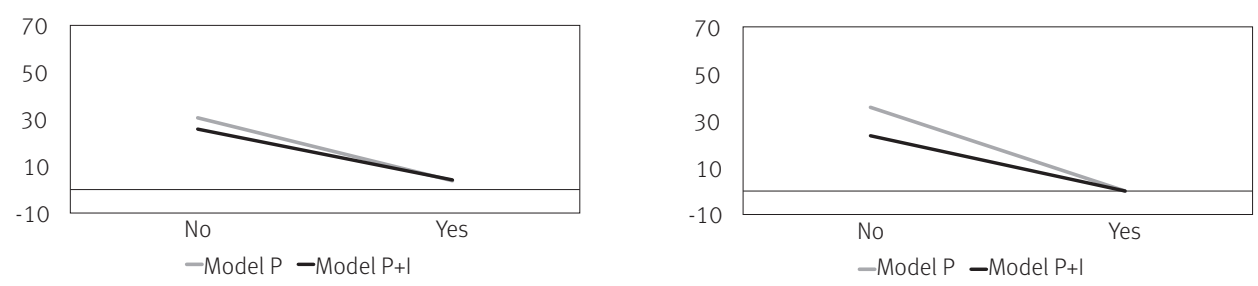

Area Used for Agriculture
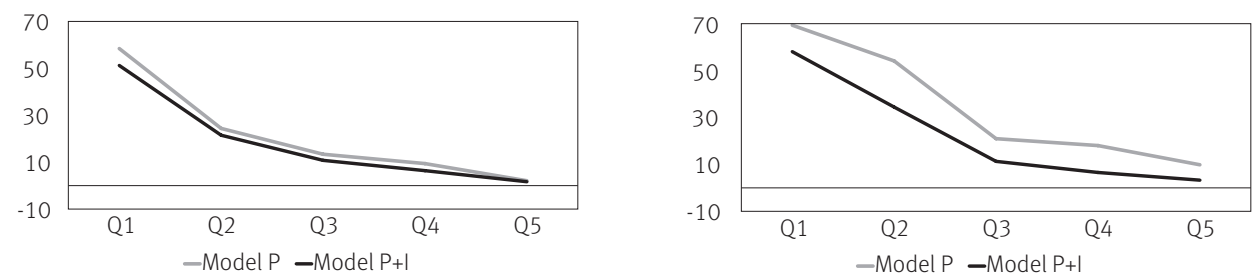

Source: Based on Altamira Survey Data (1997/98); Nang Rong Survey Data (2000).

\section{FIGURE 7}

Proportion MDP over range of livelihoods, plotted by context and model (gray $=P$, black $=P+l$ ) $-N a n g$ Rong, Thailand (2000) and Altamira, Brazil (1997/98)

Nang Rong, Thailand

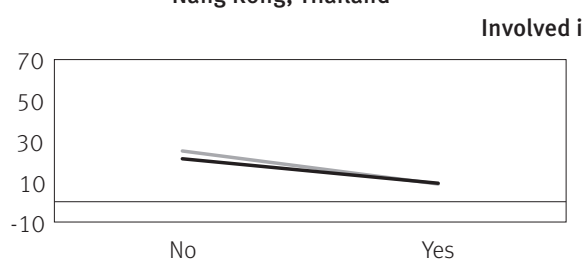

- Model P - Model P+I
Altamira, Brazil

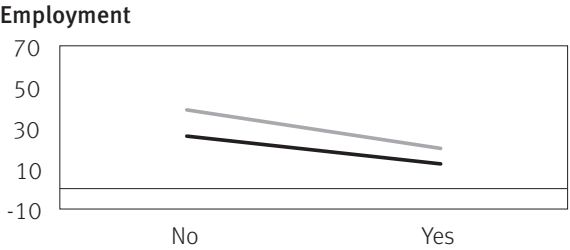

- Model P - Model P+I

Household Operates Small Business
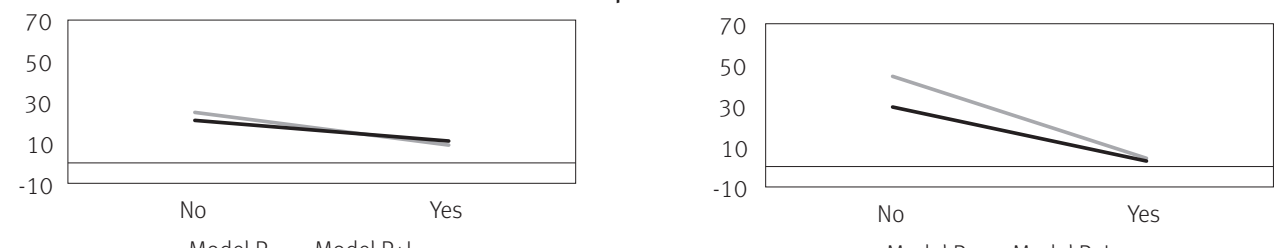

- Model P - Model P+I

Number of Livestock Owned
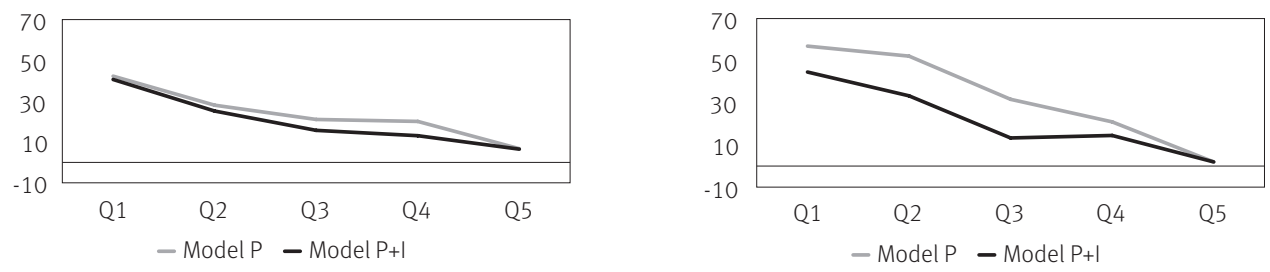

(continue) 
(conclusion)
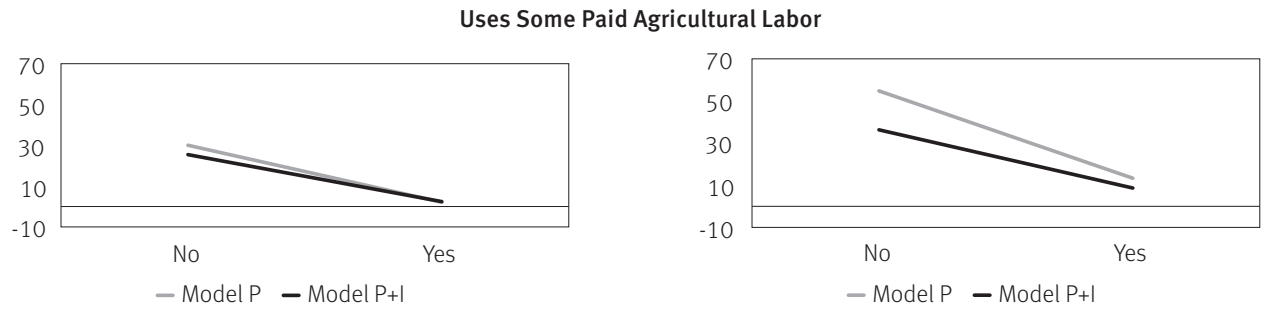

Household Demographic Dependency Ratio
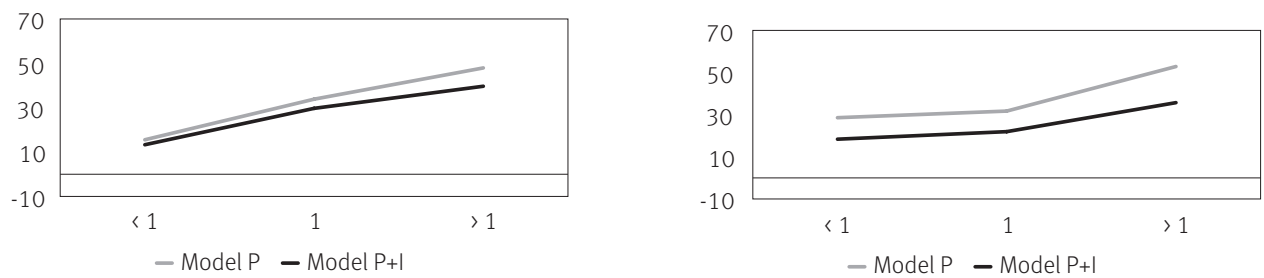

Source: Based on Altamira Survey Data (1997/98); Nang Rong Survey Data (2000).

A broad pattern of consistency across models is observable with these livelihood measures, suggesting that generalizations about the relationship of overall MDP with these selected indicators are again supported. We do, however, observe changes in the level of estimated poverty across the range of many of these variables, making it necessary to restrict the interpretation to statements about the general pattern of association between each livelihood strategy and overall MDP if we want to be conservative. All four livelihood factors - involvement in off-farm employment, ownership of a small business, participation in livestock raising, and the use of monetized agricultural labor - represent alternatives to a traditional smallholder subsistence livelihood. Thus, it comes as no surprise that we observe a comparative reduction in MDP among households that are involved in these livelihoods in both Thailand and Brazil. In each case, the effect of including additional information in model $\mathrm{P}+\mathrm{l}$ is to attenuate slightly the magnitude of this improvement, suggesting that a more nuanced measure of poverty reveals additional routes to well-being compared to a more limited measure. A similar pattern is apparent in Nang Rong, though the degree of the mitigation is slighter. The demographic dependency ratio, our proxy of household lifecycle stage, displays a consistent pattern of increasing MDP levels as the share of dependents relative to working age individuals increases. However, the greatest decline in well-being associated with dependency ratio occurs at lower levels in Nang Rong than in Altamira, indicative of contextual differences in how such demographic burdens translate into poverty.

In all, differences across contexts may be reflective of multiple causes: context, levels of commensurability and monetization, protected values, stage of frontier development. Rather than a causal model of MDP, our proposal methodology, empirically illustrated with two agricultural frontiers located in different time scales over frontier development, represents 
a way to picture overall differences and similarities that can only be fully understood by a deeper exercise of contextual characterization. In any circumstance MDP summary measures can be meaningfully compared without a close eye on temporal and spatial characterization of the territories of poverty and inequality.

\section{Discussion and conclusions}

We have presented a framework for comparison of micro-level MDP across different social and economic contexts. Our systematic approach enables researchers to compare relative MDP levels among households in settings where the constituent elements of household wellbeing may not be identical, as long as there is some shared set of common measures. With our methodological strategy, researchers compare a model that uses the full extent of information about each locale to a more limited model that can support useful comparative inferences. We believe our approach innovates in three important ways: 1) by deriving a synthetic scalar of well-being from multi-thematic survey data at the local level, taking a bottom-up like perspective on how families experience deprivation in its multiple dimensions; 2) by rendering an MDP measure robust to cross-contextual comparisons, and 3) by providing an alternative to other proposed scalars at the household/family level, such as the Family Development Index (FDI) or the Human Poverty Index (HPI), that do not explicitly incorporate a built-in sensitivity analysis or cross-site comparison and are tied to the arbitrariness of a weighting structure of dimensions.

Our methodological strategy is not intended to replace existing approaches to poverty measurement and analysis (what we term depth and breadth approaches), but rather to provide researchers with a means of making meaningful high-information comparisons across relevant contexts of interest. Because our method incorporates built-in sensitivity analyses, it helps direct attention to the nuances and qualifications that are often necessary when making valid cross-contextual comparative statements.

Our primary concern in this paper has not been the explanation of poverty, or even simply the measurement of poverty, though both of these are related. Instead, we have attempted to open the door to improved studies of the influence of context on poverty measurements. As we have shown, such cross-contextual comparisons can provide valuable generalizations that support both policy refinements and the development of other types of theory. In particular, our emphasis on the returns to various sorts of assets, whether human capital, physical capital, social capital, or others, advances ongoing efforts to characterize development and household well-being in frontier contexts, especially in tropical and subtropical regions. Our approach allows us to gauge in a more precise, quantitative way the strength of comparative statements about MDP, explicitly addressing strategies to deal with commensurability and comparability under contextual, idiomatic noise.

Our approach also encourages researchers to use site-specific knowledge derived from multiple methods - quantitative and qualitative - to inform the process of constructing MDP measures rather than relying solely on data reduction techniques. While this may seem at 
first glance to open the door wider to subjective bias, we argue that the present approach to MDP is already rife with subjectivity which becomes readily apparent when one attempts comparative work. Judgment is routinely exercised anytime research foci are chosen, measures are selected, or concepts are mapped onto indicators. While the most effective strategy for achieving better comparative measurement of MDP must obviously include systematization of these earliest stages of research planning and execution, particularly between studies, a pragmatic approach is also needed in the present moment that enables researchers to take advantage of the many large datasets already in existence. Vital to the usefulness of any such approach is that it must focus attention directly on the limitations of existing sources of data and indicators used in assessing MDP, which our approach does explicitly, opening the door wider to the high-information comparative study of MDP cross-contextually while preserving scientific integrity.

\section{References}

ALKIRE, S. Choosing dimensions: the capability approach and multidimensional poverty. Oxford: Oxford Poverty \& Human Development Initiative, 2007 (CPRC Working paper, 88).

BARROS, R. P.; CARVALHO, M.; FRANCO, S. O Índice de Desenvolvimento da Família (IDF). Rio de Janeiro: Ipea, 2003 (Texto para discussão, 986).

Pobreza multidimensional no Brasil. Rio de Janeiro: Ipea, 2006 (Texto para discussão, 1227)

BARON, J.; SPRANCA, M. Protected values. Organizational Behavior And Human Decision Processes, v. 70 , n. 1, p. 1-16, 1997

BEBBINGTON, A. Social capital and rural intensification: local organizations and islands of sustainability in the rural Andes. The Geographical Journal, v. 163, n. 2, p. 189-197, 1997.

Capitals and capabilities: a framework for analyzing peasant viability, rural livelihoods and poverty. World Development, v. 27, n. 12, p. 2021-2044, 1999.

BELLIDO, N. P.; JANO, M. D.; ORTEGA, F. J. L.; MARTÍN-GUZMÁN, M. P.; TOLEDO, M. I. The measurement and analysis of poverty and inequality: an application to Spanish conurbations. International Statistical Review, v. 66, n. 1, p. 115-131,1998.

BETTI, G.; CHELI, B.; LEMMI, A.; VERMA, V. On the construction of fuzzy measures for the analysis of poverty and social exclusion. In: INTERNATIONAL CONFERENCE TO HONOUR TWO EMINENT SOCIAL SCIENTISTS C GINI AND MO LORENZ. Annals... University of Siena 23-26 May 2005.

$\mathrm{BIBI}, \mathrm{S}$. Measuring poverty in a multidimensional perspective: a review of literature. Quebec: PEP, 2005 (Working paper PMMA, 2005-07).

BRADY, D.; FULLERTON, A. S.; CROSS, J. M. Putting poverty in political context: a multi-level analysis of adult poverty across 18 affluent democracies. Social Forces, v. 88, n. 1, p. 271-299.

BRONDIZIO, E.S.; MCCRACKEN, S. D.; MORAN, E. F.; SIQUEIRA, A.D.; NELSON, D.R.; RODRIGUEZ-PEDRAZA, C. The Colonist footprint: toward a conceptual framework of deforestation trajectories among small farmers in frontier Amazônia. In: WOOD, C.; PORRO, R. (Eds.). Deforestation and land use in the Amazon. Gainesville, Florida: University Press of Florida,2002, p. 133-161.

CARNEIRO, M. J. Herança e gênero entre agricultores familiares. Estudos Feministas, v. 9, p. 22-55, 2001. 
CARNEY, D. (Ed.). Sustainable rural livelihoods. What contribution can we make? London: Department for International Development (DFID), 1998.

CHAKRAVARTY, S.; SILBER, J. Measuring multidimensional poverty: the axiomatic approach. In: KAKWANI, N.; SILBER, J. (Eds.). Quantitative approaches to multidimensional poverty measurement. New York: Palgrave MacMillan, 2008, p. 192-209.

CHASE-DUNN, C.; KAWANO, Y.; BREWER, B. D. Trade globalization since 1795: waves of intergration in the world-system. American Sociological Review, v. 65, n. 1, p. 77-95, 2000.

CHELI, B. Totally fuzzy and relative measures of poverty in dynamic context. Metron, v. 53, n. 3-4, p. 183-205, 1995.

CHELI, B.; LEMMI, A. A “Totally” fuzzy and relative approach to the multidimensional analysis of poverty. Economic Notes, v. 24, p. 115-134, 1995.

CHEN, S.; RAVALLION, M. Absolute poverty measures for the developing world, 1981-2004. PNAS, V. 104, n. 43, p. 16757-16762, 2007.

CHIAPPERO-MARTINETTI, E. Complexity and vagueness in the capability approach: strengths or weaknesses. In: ALKIRE, S.; COMIM, F.; QIZILBASH, M. (Eds.). The capability approach in human development: concepts, applications and measurement. 2004.

DE SHERBININ, A.; VANWEY L. K.; MCSWEENEY, K.; AGGARWAL, R.; BARBIERI, A.; HENRY, S.; HUNTER, L. M.; TWINE, W.; WALKER, R. Rural household demographics, livelihood and the environment. Global Environmental Change, v. 18, p. 38-53, 2008.

DORFMAN, R. A formula for the Gini Coefficient. The Review of Economics and Statistics, v. 61, n. 1 , p. 146-149, 1979.

ELLIS, F. Household strategies and rural livelihood diversification. Journal of Development Studies, v. 35 , n. 1, p. $1-38,1998$.

FOSTER, J.; GREER, J.; THORBECKE, E. A class of decomposable poverty measures. Econometrica, v. 52, n. 3, p. $761-766,1984$.

GARCIA, R. A.; SOARES-FILHO, B. S.; SAWYER, D. O. Socioeconomic dimensions, migration, and deforestation: an integrated model of territorial organization for the Brazilian Amazon. Ecological Indicators, v. 7, n. 3, p. 719-730, 2007.

GRANDSTAFF, T. B. The human environment: variation and uncertainty. Pacific Viewpoint, v. 334, p. 134-144, 1992.

GUEDES, G. R., CARMO, R. L. Socioeconomic and residential differences in environmental perception and behavior: insights from metropolitan Brazil. In: TURUNEN, E.; KOSKINEN, A. (Eds.). Urbanization and the global environment. New York: Nova Publishers, 2012.

GUEDES, G. R., QUEIROZ, B. L. To whom shall i leave it? Land inheritance in the Brazilian Amazon. In: POPULATION ASSOCIATION OF AMERICA. Annals... New Orleans, 2008.

GUEDES, G. R.; QUEIROZ, B. L.; VANWEY, L. K. Transferências intergeracionais privadas na Amazônia rural brasileira. Nova Economia, v. 19, n. 2, p. 325-357, 2009.

GUEDES, G. R.; BRONDÍZIO, E. S.; BARBIERI, A. F.; RESENDE, A.; PENNA-FIRME, R; D’ANTONA, A. O. Poverty and inequality in the rural Brazilian Amazon: a multidimensional approach. Human Ecology, v. 40, p. 41-57, 2012.. DOI: 10.1007/s10745-011-9444-5.

HOFFMANN, R. Distribuição de renda: medidas de desigualdade e pobreza. São Paulo: Edusp, 1998. HULL, J.R. Migration, remittances, and monetization of farm labor in subsistence sending areas. Asian and Pacific Migration Journal, v. 16, n. 4, 2007. 

Chapel Hill, 2010.

KAKWANI, N.; SILBER, J. The many dimensions of poverty. New York: Palgrave MacMillan, 2008a.

Quantitative approaches to multidimensional poverty measurement. New York: Palgrave MacMillan, 2008b.

KRISNAKUMAR, J. Multidimensional measures of poverty and well-being based on latent variable models. In: KAKWANI, N.; SILBER, J. (Eds.). Quantitative approaches to multidimensional poverty measurement. New York: Palgrave MacMillan, 2008, p. 118-134.

LAWSON, D.; MCKAY, A.; OKIDI, J. Poverty persistence and transitions in Uganda: a combined qualitative and quantitative analysis. Journal of Development Studies, v. 42, n. 7, p. 1225-1251, 2006.

LUDEWIGS, T.; D’ANTONA, A.O.; BRONDIZIO, E. S.; HETRICK, S. Agrarian structure and land use change along the lifespan of three colonization areas in the Brazilian Amazon. World Development, v. 37, n. 10, p. 1348-1359, 2009.

LUZZI, G. F.; FLÜCKIGER, Y.; WEBER, S. A cluster analysis of multidimensional poverty in Switzerland. In: KAKWANI, N.; SILBER, J. (Eds.). Quantitative approaches to multidimensional poverty measurement. New York: Palgrave MacMillan, 2008, p. 63-79.

MANTON, K. G.; WOODBURY, M. A.; TOLLEY, H. D. Statistical application using fuzzy sets. New York: John Wiley \& Sons, 1994.

MCCRACKEN, S. D.; SIQUEIRA, A. D.; MORAN, E. F.; BRONDIZIO, E. S. Land use patterns on an agricultural frontier in Brazil: insights and examples from a demographic perspective. In: WOOD, C.; PORRO, R. (Eds.). Deforestation and land use in the Amazon. Gainesville, Florida: University Press of Florida,

PRENDERGAST, C.; STOLE, L. Non-monetary exchange within firms and industry. Cambridge, MA: National Bureau of Economic Research - NBER, 1996 (Working paper, 5765).

RAMOS, X. Using efficiency analysis to measure individual wellbeing with an illustration for Catalonia. In: KAKWANI, N.; SILBER, J. (Eds.). Quantitative approaches to multidimensional poverty measurement. New York: Palgrave MacMillan, 2008, p. 155-175.

RIGG, J. Southeast Asia: the human landscape of modernization and development. London: Routledge, 2003.

RINDFUSS, R.; ENTWISLE, B.; WALSH, S. Nang Rong Projects [Thailand] [Computer file], Inter-University Consortium for Political and Social Research [distributor], Ann Arbor, MI, 2009.

SAWYER, D. O.; LEITE, I. C.; ALEXANDRINO, R. Perfis de utilização de serviços de saúde no Brasil. Ciência \& Saúde Coletiva, v. 7, n. 4, p. 757-776, 2002.

SEN, A. K. Commodities and capability. Oxford: Oxford University Press, 1985.

The standard of living. New York, NY: Cambridge University Press, 1989.

STEWART, Q. T. Reinvigorating relative deprivation: a new measure for a classic concept. Social Science Research, v. 35, p. 779-802, 2006.

THOMAS, D. Village land use in Northeast Thailand: predicting the effects of development policy on village use of wild lands. Ann Arbor: UMI, 1988.

VANWEY, L. K.; CEBULKO, K. B. Intergenerational coresidence among small farmers in Brazilian Amazonia. Journal of Marriage and the Family, v. 69, n. 5, p. 1257-1270, 2007.

VANWEY, L. K.; D'ANTONA, A. O.; BRONDIZIO, E. S. Household demographic change and land use. Population and Environment, v. 28, n. 3, p. 163-185, 2007. 
VANWEY, L. K.; GUEDES, G. R.; D’ANTONA, A. O. Out-migration and land-use change in agricultural frontiers: insights from Altamira settlement project. Population and Environment, 2011 (Online first). DOI: DOI 10.1007/s11111-011-0161-1.

VANWEY, L. K.; HULL, J. R.; GUEDES, G. Capitals and Context: bridging health and livelihoods in smallholder frontiers. In: KELLEY CREWS, K.; KING, B. (Eds.). The politics and ecologies of health. New York: Routledge, 2013..

ZELIZER, V. A. The social meaning of money: 'special monies. The American Journal of Sociology, v. 95, n. 2, p. 342-377, 1989.

. The social meaning of money: pin money, paychecks, poor relief, and other currencies. Princeton, NJ: Princeton University Press, 1997.

\section{Resumo}

\section{Reconstruindo Babel: comparando o bem-estar multidimensional de diferentes contextos culturais em busca de soluções comuns para o desenvolvimento}

Com base na tradição teórica relativa a estratégias de sobrevivência e portfólios de capitais, propõe-se uma adaptação e combinação de metodologias existentes para análise do bem-estar em domicílios rurais, com especial atenção à comparação entre diferentes contextos. Em primeiro lugar, estimou-se uma medida multidimensional de pobreza, baseada em lógica nebulosa, para duas áreas de fronteira agrícola: Nang Rong, na Tailândia, e Altamira, no Brasil. Para que a comparação entre os contextos fosse possível, uma segunda estimativa foi obtida, utilizando-se um subconjunto das medidas presentes nas duas áreas de estudo. Os resultados sugerem que o padrão de resposta em relação a várias características-chave - por exemplo, educação, renda e razão de dependência demográfica - é robusto à especificação do modelo. Conclui-se que generalizações comparativas, úteis na formulação de políticas públicas que sejam custo-eficientes quanto à intervenção em contextos distintos, poderiam ser identificadas em diversas situações. Mais genericamente, a presente abordagem fornece aos pesquisadores e gestores de políticas um arcabouço que possibilite entender a interação do contexto com a construção subjetiva de bem-estar. A compreensão dessa interação é útil para distinguir corolários estáveis de pobreza daqueles que são voláteis em contextos distintos.

Palavras-chave: Pobreza multidimensional. Amazônia. Tailândia.

\section{Resumen}

Reconstruyendo Babel: la comparación del bienestar multidimensional de diferentes contextos culturales en búsqueda de soluciones comunes para el desarrollo

En base a la tradición teórica relativa a estrategias de supervivencia y carteras de capitales, se propone una adaptación y combinación de metodologías existentes para analizar el bienestar en viviendas rurales, con especial atención a la comparación entre diferentes contextos. En primer lugar, se estimó una medida multidimensional de pobreza, basada en lógica nebulosa, para dos áreas de frontera agrícola: Nang Rong, en Tailandia, y Altamira, en Brasil. Para que la comparación entre los contextos fuese posible, se llegó a una segunda estimación, utilizando un subconjunto de las medidas presentes en las dos áreas de estudio. Los resultados sugieren que el patrón de respuesta en relación a varias características clave - por ejemplo, educación, ingresos y razón de dependencia demográfica - es robusto en lo que 
concierne a la especificación del modelo. Se concluye que generalizaciones comparativas, útiles en la formulación de políticas públicas costo-eficientes en lo que se refiere a la intervención en contextos distintos, podrían identificarse en diversas situaciones. Más genéricamente, el presente abordaje ofrece a investigadores y gestores de políticas una base que posibilite entender la interacción del contexto con la construcción subjetiva de bienestar. La comprensión de esta interacción es útil para distinguir corolarios estables de pobreza de aquellos que son volátiles en contextos distintos.

Palabras clave: Pobreza multidimensional. Amazonia. Tailandia. Comparación entre contextos. Grade of Membership.

Recebido para publicação em 20/12/2011

Aceito para publicação em 24/02/2012 